\title{
Diversity of mollusks (bivalves and gastropods) in degraded mangrove ecosystems of Kolaka District, Southeast Sulawesi, Indonesia
}

\author{
LA ODE ABDUL FAJAR HASIDU ${ }^{1, \bullet}$, JAMILI $^{2}$, GABY NANDA KHARISMA ${ }^{3}$, ARIF PRASETYA ${ }^{4}$, \\ MAHARANI ${ }^{1}$, RISKA $^{1}$, LA ODE ADI PARMAN RUDIA ${ }^{2}$, AKHMAD FADLI IBRAHIM ${ }^{5}$, \\ AZHAR ARAS MUBARAK ${ }^{6}$, LA ODE MUHSAFAAT ${ }^{7}$, LUTHFI ANZANI ${ }^{8}$ \\ ${ }^{1}$ Department of Marine Science, Faculty of Agriculture, Fisheries, and Animal Husbandry, Universitas Sembilanbelas November Kolaka. Kampus B, J1. \\ Jend. Sudirman, Mawasangka, Buton Tengah 93762, Indonesia. "email: fajarhasidu90@ gmail.com \\ ${ }^{2}$ Department of Biology, Faculty of Mathematics and Natural Sciences. Universitas Halu Oleo. Kambu, Kendari 93232, Southeast Sulawesi, Indonesia \\ ${ }^{3}$ Department of Geography Education, Faculty of Teacher Training and Education, Universitas Sembilanbelas November Kolaka. Jl. Pemuda, Kolaka \\ 93561, Southeast Sulawesi, Indonesia \\ ${ }^{4}$ Department of Fisheries, Faculty of Agriculture, Fisheries, and Animal Husbandry, Universitas Sembilanbelas November Kolaka. Jl. Pemuda, Kolaka \\ 93561, Southeast Sulawesi, Indonesia \\ ${ }^{5}$ Department of Mechanichal Engineering, Faculty of Science and Technology, Universitas Sembilanbelas November Kolaka. J1. Pemuda, Kolaka 93561, \\ Southeast Sulawesi, Indonesia \\ ${ }^{6}$ Department of Naval Engineering, Faculty of Science and Technology, Universitas Sembilanbelas November Kolaka. Kampus B, Jl. Jend. Sudirman, \\ Mawasangka, Buton Tengah 93762, Indonesia \\ ${ }^{7}$ Department of Animal Husbandry, Faculty of Agriculture, Fisheries, and Animal Husbandry, Universitas Sembilanbelas November Kolaka. Jl. Pemuda, \\ Kolaka 93561, Southeast Sulawesi, Indonesia \\ ${ }^{8}$ Department of Marine Information System, Universitas Pendidikan Indonesian. Jl. Dr. Setiabudi No. 229, Bandung 40154, West Java, Indonesia
}

Manuscript received: 3 July 2020. Revision accepted: 29 November 2020.

\begin{abstract}
Hasidu LOAF, Jamili, Kharisma GN, Prasetya A, Maharani, Riska, Rudia LOAP, Ibrahim AF, Mubarak AA, Muhasafaat LO, Anzani L. 2020. Diversity of mollusks (bivalves and gastropods) in degraded mangrove ecosystems of Kolaka District, Southeast Sulawesi, Indonesia. Biodiversitas 21: 5884-5892. Mollusks are one of the mangrove organisms whose classes are bivalves and gastropods. It plays an important role in mangrove and marine ecosystems as filter feeders, predators, and herbivores. This study aims to knows the diversity and abundance of mollusks (bivalves and gastropods) in several mangrove ecosystems in the Kolaka coastline as well as the similarity of these locations. This study was conducted in mangrove ecosystems of Induha Village, Mangolo Village, Tahoa Village, and Towua Village of Kolaka District, Southeast Sulawesi, Indonesia, from July to August 2019. This is a transect method stretched along a $100 \mathrm{~m}$ line perpendicularly from the seaward. The size of the mollusks subplot was $1 \mathrm{~m}^{2}$ and placed along the line transect. Each line transect comprises 10 subplots. To analyze the diversity index, evenness index, and its abundance, Kaleida Graph 4.0 version was used. This research indicates that the mollusks consist of 4 families of bivalves with 6 species and 10 families of gastropods with 182 species. It also found out 23 species of mollusks scattered to each location. The molluscan species which spread in all four mangrove ecosystems were Terebralia sulcata, Nerita planospira, and Batillaria multiformis. In Induha, the mollusks species were Anadara notabilis and Drupella margariticola. Meanwhile, Saccostrea cucullata, Pirenella incisa, Clithon oualaniensis, and Clithon pulchellum were only found in Towua. The diversity index of bivalves in each location was categorized as low diversity index category, as well as gastropods were categorized as medium diversity index. The highest diversity index of gastropods was in Induha $\left(\mathrm{H}^{\prime}=1.96\right)$. It was supported by the good mangrove ecosystem for mollusks' habitat. The lowest diversity index of gastropods was in Towua (1.41). This research depicts that three kinds of species with high abundance rate whose rates were $>1 \mathrm{ind} / \mathrm{m}^{2}$ are located in two different locations namely; $P$. incisa $\left(3.9 \mathrm{ind} / \mathrm{m}^{2}\right)$ and $S$. cucullata $\left(3.2 \mathrm{ind} / \mathrm{m}^{2}\right)$ in Towua and followed by B. multiformis $\left(2 \mathrm{ind} / \mathrm{m}^{2}\right)$ and Isognomon ephippium $\left(1.2 \mathrm{ind} / \mathrm{m}^{2}\right)$ in Mangolo.
\end{abstract}

Keywords: Bivalves, diversity, gastropods, mangroves ecosystem, mollusks

\section{INTRODUCTION}

Mangrove ecosystem has a high biodiversity value in which various aquatic organisms (Murniati and Pratiwi 2015), such as mollusks are discovered in this ecosystem. This ecosystem has various benefits (Kristiningrum et al. 2019). Not only for a habitat of various types of marine and coastal plants, but also a nursery ground and feeding ground for some certain animals including endemic animals (Aksornkoae 1993; Septiana et al. 2016). Ecologically, mangroves could reduce atmospheric $\mathrm{CO}_{2}$ (Analuddin et al. 2020). Therefore, if the mangrove ecosystem degrades, the biggest possible impact occurred is biodiversity loss and ecological imbalance. To prevent the loss of biodiversity potency in a mangrove ecosystem, it is necessary to introduce conservation campaigns. Data on biodiversity is also needed to support conservation.

Mollusks are one of the mangrove organisms whose class are bivalves and gastropods. It plays an important role in the mangrove and marine ecosystem (Kartika and $\mathrm{Mu}$ 2014; Satyanarayana and Krishna 2017; Ngor et al. 2018). Mollusks are macrobenthic organisms that dominate in mangrove ecosystem (Satheeshkumar and Khan 2012). They are filter feeders, predators, and herbivores (Cannicci 
et al. 2008; Sharma et al. 2013; Suratissa and Rathnayake 2017). Meanwhile, decomposer in food webs or consumerresource systems provides organic materials in the mangrove ecosystem (Bhosale et al. 2016; Satyanarayana and Krishna 2017). Besides, several species of mollusks are used for food sources in the community (Szabó and Amesbury 2011; Flores-Garza et al. 2012). Saleky et al. (2016) state that some Indonesian communities, especially in Papua utilize the gastropods as the food source. In addition, it has an economic value in the handcraft industry, especially from bivalves and mollusks shells (Dolorosa and Dangan-Galon 2014). It probably could have an impact on the population in the ecosystem (Saleky et al. 2016). If the presence of mollusks (both bivalves and gastropods) was a distraction as the impact of mangrove degradation, the population and diversity will decrease. Moreover, an ecosystem imbalance will occur. The organic matter supply for the food chain will be stopped as the mollusks are decreasing in numbers because they serve as a decomposer in the food chain, decreasing of herbivore, as well as losing of alternative sources of protein for the coastal community.

Kolaka is one of the districts in Southeast Sulawesi which experiences mangrove ecosystem degradation. According to the field observation of the preliminary study, the mangrove ecosystem along the coastline of Kolaka
District has been degraded by anthropogenic activities due to various development, for instance, the ecosystem converted to be pond and community settlement. If this activity occurs continuously over a long period, it might lead to damage to the mollusks' habitat and reduce the biodiversity value. Nevertheless, some parts of the coastline of Kolaka have been successfully rehabilitated.

Nowadays, the presented data of mangrove mollusks diversity in Indonesia is still limited. It is considered a considerable threat to biodiversity. Therefore, it is crucial to observe the mollusks' biodiversity in the mangrove ecosystem along the coastline of Kolaka. The present study aims to obtain inventories of the mollusks diversity (bivalves and gastropods) in several mangrove ecosystems along the coastline of Kolaka District, Southeast Sulawesi, Indonesia.

\section{MATERIALS AND METHODS}

\section{Study site}

This study was conducted from July to August 2019 and is located in several mangrove ecosystems along the Kolaka coastline, Southeast Sulawesi Province, Indonesia namely: Induha Village, Mangolo Village, Tahoa Village, and Towua Village (Figure 1).

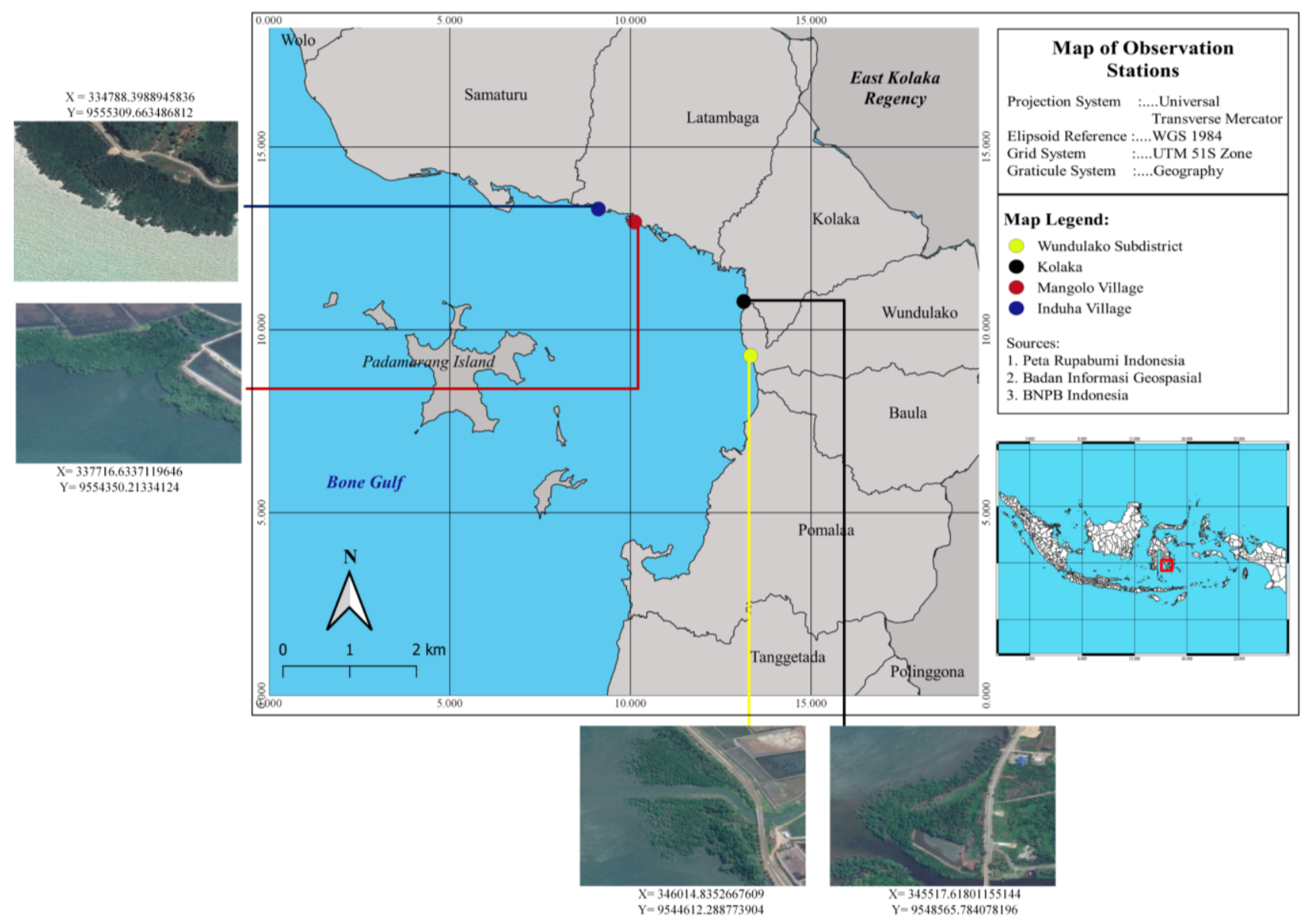

Figure 1. The four locations of study site in degraded mangrove ecosystems of Kolaka District, Southeast Sulawesi, Indonesia: 1. Induha Village, 2. Mangolo Village, 3. Tahoa Village, and 4. Towua Village 
Mangrove ecosystem of Towua has located nearby mining industries and shrimp/fish ponds. Meanwhile, the Tahoa mangrove ecosystem is nearby the Kolaka town area as well as fish/shrimp ponds. Different from Tahoa and Towua, Induha and Mangolo mangrove ecosystems are relatively far from the residential area and mining industries, but besides the shrimp/fish ponds.

\section{Sampling procedure}

The ecological data of mollusks in the mangrove ecosystem was obtained by placing 10 subplots sized $1 \mathrm{~m}^{2}$ along $100 \mathrm{~m}$ line transect, perpendicular to the coastline (Kantharajan et al. 2017). Each Mollusca found in the subplots, both on the surface of substrate, roots, stem, and mangrove leaves as well as in the substrate were collected. All samples were then counted to know the total number of each individual and species.

\section{Data analysis}

The family and species identification of mollusks (bivalves and gastropods classes) were done using Dey (2006) and Dharma (1991). The data of mollusks that had been collected was then analyzed descriptively. Each quantitative parameter of the data was analyzed by Shannon-Wiener's diversity index, evenness index, and Simpson's dominance index (Analuddin et al. 2013). Besides that, the similarity index of Bray-Curtis is to compare and contrast the four locations to gather the similarity and differences of each site.

Shannon-Wiener diversity index (English et al. 1997)

$$
\mathbf{H}^{\prime}=-\sum_{\mathrm{i}}^{\mathrm{s}}=\mathrm{Pi} \operatorname{Ln} \mathrm{Pi}
$$

Where:

$\mathrm{Pi}=$ ni/ $\mathrm{N}$

$\mathrm{H}^{\prime}$ :diversity index (Shannon-Wiener index of diversity)

$\mathrm{Ni}$ : total individuals of $i$ species

$\mathrm{N}$ : total individuals of all species

$S$ : total species in the community

$\mathrm{Pi}$ : the proportion of $\mathrm{S}$ which formed by the $i$ species

The criteria of the diversity index were:

$\mathrm{H}^{\prime}<1$ : low diversity index

$1 \leq \mathrm{H}^{\prime} \leq 3$ : medium diversity index

$\mathrm{H}^{\prime}>3$ : high diversity index

Evenness index (Pileou's evenness index)

$$
\mathrm{E}=\frac{\mathrm{H}^{\prime}}{\mathrm{H}^{\prime} \max }
$$

$$
\operatorname{Hax}=-\sum_{i=1}^{s} \frac{1}{\mathrm{~S}} \operatorname{Ln} \frac{1}{\mathrm{~S}}=\ln \mathrm{S}
$$

Where:

$\mathrm{E}=$ evenness index (Pileou's evenness index)

$\mathrm{H}^{\prime}=$ diversity index

H'max = maximum diversity index
Evenness criteria according to (Baderan et al. 2019): (i) $<0.20$ : very poor category/the condition of community structures is not equal, (ii) 0.21-0.40: poor category/the condition of community structures is fairly equal, (iii) 0.41 0.60: medium category/the condition of community structures is equal, (iv) 0.61-0.80: good condition category/the condition of community structures is more equal, (v) > 0.81: very good condition category/the condition of community structures is very equal.

\section{The abundance of each species (Shannon-Wiener in Odum} and Barrett 2004)

Abundance is the amount obtained by calculating the number of individuals per $\mathrm{m}^{2}$ that are divided by the area $\left(\mathrm{m}^{2}\right)$ as shown in the following formula:

$$
\mathrm{Di}=\mathrm{Ni} / \mathrm{A}
$$

Where: Di is the density of mollusk (individuals $/ \mathrm{m}^{2}$ ), Ni is the number of individuals (ind), $\mathrm{A}$ is the area $\left(\mathrm{m}^{2}\right)$.

\section{RESULTS AND DISCUSSION}

\section{Distribution of mollusks}

The mollusks found in several locations of the mangrove ecosystem along the Kolaka coastline consisted of four families of bivalves and ten families of gastropods. Both classes were scattered to four locations (Table 1).

The distribution of mollusks in each mangrove ecosystem indicates different features for each species. However, there are mollusk species found in all-four locations simultaneously, namely Terebralia sulcata, Nerita planospira, and Batillaria multiformis. While the species seen in only one location are Anadara notabilis, Pirenella incisa, Clithon oualaniensis, Clithon pulchellum, Littoraria intermedia, Clypeomorus pellucida, dan Drupella margariticola (Table 1).

\section{Diversity and evenness of mollusks species}

The mollusks in Kolaka coastal line consist of bivalves (4 families and 6 individuals), and gastropods (10 families and 182 individuals). Therefore, the total of mollusks species in all locations is 23 species (15 species in Induha, 12 species in Mangolo, 8 species in Tahoa, and 13 species in Towua) (Figure 2).

Shannon-Wiener diversity index, Pileou's evenness index, and dominance index of mollusks species in all locations are clearly shown in the following Figure 3. There are differences in the Shannon-Wiener diversity index in all locations. The highest diversity index of bivalves is exhibited in Induha (0.45), while the lowest is in the Towua (0.36). The highest diversity index of gastropods is in Induha (1.96) and the lowest is in Towua (1.41). In general, the diversity index in each location for Bivalviaspecies is categorized in a poor index diversity $(\mathrm{H}$ ' $<1)$. Nevertheless, the gastropods are identified as a middle-index diversity $\left(1<\mathrm{H}^{\prime} \leq 3\right)$. 
Table 1. Distribution of mollusks species in mangrove ecosystem of Kolaka coastline, Southeast Sulawesi, Indonesia

\begin{tabular}{|c|c|c|c|c|c|}
\hline \multirow[b]{2}{*}{ Family } & \multirow[b]{2}{*}{ Species } & \multicolumn{4}{|c|}{ Location } \\
\hline & & & 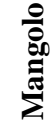 & 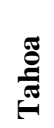 & $\stackrel{9}{8}$ \\
\hline \multicolumn{6}{|l|}{ Bivalves } \\
\hline Cyrenidae & Geloina erosa & + & + & - & - \\
\hline Acridae & Anadara notabilis & + & - & - & - \\
\hline Petriidae & Isognomon ephippium & + & + & - & - \\
\hline Ostreoidae & Saccostrea cucullata & - & - & - & + \\
\hline Subtotal & & 3 & 2 & 0 & 1 \\
\hline \multicolumn{6}{|l|}{ Gastropods } \\
\hline \multirow[t]{3}{*}{ Potamididae } & Telescopium telescopium & + & + & - & + \\
\hline & Terebralia sulcata & + & + & + & + \\
\hline & Pirenella incisa & - & - & - & + \\
\hline \multirow[t]{4}{*}{ Neritidae } & Nerita planospira & + & + & + & + \\
\hline & Clithon oualaniensis & - & - & - & + \\
\hline & Clithon pulchellum & - & - & - & + \\
\hline & Clithon sp. & - & - & + & + \\
\hline \multirow[t]{3}{*}{ Littorinidae } & Littoraria pallescens & + & + & - & - \\
\hline & Littoraria carinifera & + & + & + & - \\
\hline & Littoraria intermedia & - & - & + & - \\
\hline \multirow[t]{2}{*}{ Cerithiidae } & Cerithium corallium & + & + & - & - \\
\hline & Clypeomorus pellucida & - & - & - & + \\
\hline \multirow[t]{2}{*}{ Muricidae } & Chicoreus capucinus & - & - & + & + \\
\hline & Drupella margariticola & + & - & - & - \\
\hline Ellobiidae & Cassidula aurisfelis & + & + & - & - \\
\hline Pachychilidae & Faunus ater & + & - & + & + \\
\hline Batillariidae & Batillaria multiformis & + & + & + & + \\
\hline Turridae & Lophiotoma polytropa & + & + & - & - \\
\hline Melongenidae & Volema myristica & + & + & - & + \\
\hline Subtotal & & 12 & 10 & 8 & 12 \\
\hline Total & & 15 & 12 & 8 & 13 \\
\hline
\end{tabular}

Note: +: presence; -: absence

Meanwhile, the highest Pileou's evenness index of bivalves species is in Mangolo (0.60), and the lowest is in Induha (0.41), while the highest Pileou's evenness index of gastropods species is in Tahoa (0.92), and the lowest is in Towua (0.58). Generally, the Bivalvia evenness index is categorized in middle to high index, yet for Gastropoda, it is middle, high, and even very high index. However, no bivalves species are found in Tahoa, so the diversity and evenness index in this location is 0 (Figures 3 ).

\section{The abundance of mollusks species}

The abundance rate of mollusk (Bivalvia and Gastropoda) in each research location indicates a distinctive abundance. Several mollusks have high, medium, and low rates of abundance. This is presented in the following graphs.

According to the graph of mollusks abundance in each research location (Figure 4 ), it is profounded that mollusk species in Induha is about 0.1 to $0.9 \mathrm{ind} / \mathrm{m}^{2}$. From 15 species found in this location, four species have high rate abundance, namely $B$. multiformis $\left(0.9 \mathrm{ind} / \mathrm{m}^{2}\right), \quad L$. pallescens $\left(0.8 \mathrm{ind} / \mathrm{m}^{2}\right), T$. sulcata $\left(0.8 \mathrm{ind} / \mathrm{m}^{2}\right)$, and $I$. ephippium $\left(0.7 \mathrm{ind} / \mathrm{m}^{2}\right)$. Moreover, the abundance in
Mangolo depicts a variety of abundance rates in the range of 0.1 to $2 \mathrm{ind} / \mathrm{m}^{2}$. Of 12 species found, two species have high rate abundance, namely $B$. multiformis $\left(2 \mathrm{ind} / \mathrm{m}^{2}\right)$, dan I. ephippium $\left(1.2 \mathrm{ind} / \mathrm{m}^{2}\right)$. Meanwhile, mollusks in Tahoa are about 0.1 to $0.7 \mathrm{ind} / \mathrm{m}^{2}$ which two out of eight species have a high abundance rate, namely $N$. planospira $(0.7$ ind $/ \mathrm{m}^{2}$ ) dan Clithon sp. (0.6). In Towua, the abundance rate also shows a high rate which is 0.1 to $3.9 \mathrm{ind} / \mathrm{m}^{2}$. From 13 species, two species have a high category which is $P$. incisa (3.9 ind $\left./ \mathrm{m}^{2}\right)$, and $S$. cucullata $\left(3.2 \mathrm{ind} / \mathrm{m}^{2}\right)$.

Based on the similarity and dissimilarity indexes in Table 2, it reveals that the highest similarity index is in Induha and Mangolo (similarity $=0.953271$; and dissimilarity $=0.046729$ ), while the least similarity index is in Tahoa and Towua (similarity $=0.427481$; and dissimilarity $=0.572519$ ). The highest similarity index presents a similar condition of the location, yet the high dissimilarity index signs different characteristics of two locations.

\section{Similarity and dissimilarity indexes in each location}

The similarity and dissimilarity indexes among four locations are shown in Table 2.

\section{Diversity of mollusks in several mangrove ecosystems in Indonesia}

The diversity of mollusks (Bivalvia dan Gastropoda) in each location is shown in Table 3.

According to Table 3, the number of mollusks species in this study is in the poor category. The mangrove ecosystem of Lombok island and Ambon bay have more mollusks species. The number of species has no differences from species in North Sulawesi and Aceh. However, the number of species of gastropods in this study is higher than the gastropods species in Brebes (Central Java), Nirwana Coast (Padang, West Sumatra), and Mojo Village, (Pemalang District, Central Java).

\section{Discussion}

Mangrove is a habitat for several coastal organisms like mollusks as a feeding ground, nursery ground, and spawning ground (Yadav et al. 2019). Mangrove ecosystem could provide the sustainability and juvenile availability of the associated organisms like bivalves and gastropod's juvenile (Bhosale et al. 2016). Both classes of gastropods and bivalves are important biotic components in mangrove ecosystem (Zvonareva and Kantor 2016; Htwe and Oo 2019), functioning as a decomposer in food webs which provides organic materials in the mangrove ecosystem (Bhosale et al. 2016; Satyanarayana and Krishna 2017).

Mangrove litter on the ground of the ecosystem will be decomposed by organic decomposers, including mollusks. The process will produce organic materials which are later harnessed back by mangrove trees as nutrition resources. This process will stimulate the presence and biodiversity of mollusks, both bivalves, and gastropods (Baderan et al. 2019).

This study shows the differences in mollusks composition in Tahoa coastline, both bivalves and 
gastropods classes. Induha, Mangolo, and Towua have various bivalves and gastropods compared to four locations. Overall, gastropod species dominate the study location compared to bivalves. The same results are obtained by (Baderan et al. 2019; Htwe and Oo 2019; Irma and Sofyatuddin 2012), which find more and dominant gastropod species in the mangrove ecosystem. It is caused by the good adaptation ability of gastropods.
Table 2. similarity and dissimilarity indexes among four locations of mangrove ecosystem in Kolaka, Southeast Sulawesi, Indonesia

\begin{tabular}{lllll}
\hline $\begin{array}{l}\text { Similarity } \\
\text { Dissimilarity }\end{array}$ & Induha & Mangolo & Tahoa & Towua \\
\hline Induha & & 0.953271 & 0.666667 & 0.704403 \\
Mangolo & 0.046729 & & 0.708861 & 0.662338 \\
Tahoa & 0.333333 & 0.291139 & & 0.427481 \\
Towua & 0.295597 & 0.337662 & 0.572519 & \\
\hline
\end{tabular}

Table 3. The diversity of mollusks in several mangrove ecosystems in Indonesia

\begin{tabular}{lccl}
\hline Location & No. of bivalve & No. of gastropod & References \\
\hline Lombok Island, West Nusa Tenggara & 5 & 42 & Candri et al. (2018) \\
Ambon Bay, Maluku & 9 & 24 & Islami and Mudjiono (2009) \\
South Bolaang Mangodow, North Sulawesi & 3 & 21 & Baderan et al. (2019) \\
Aceh Besar and Banda Aceh, Aceh & 5 & 14 & Irma and Sofyatuddin (2012) \\
Brebes, Central Java & - & 10 & Nurfitriani et al. (2019) \\
Nirwana Coast, Padang City, West Sumatra & - & 15 & Yolanda et al. (2015) \\
Mojo Village, Pemalang District, Central Java & - & 8 & Puryono and Suryanti (2019) \\
Kolaka, Southeast Sulawesi & 4 & 19 & This study \\
\hline
\end{tabular}

Note: - = not included in the study

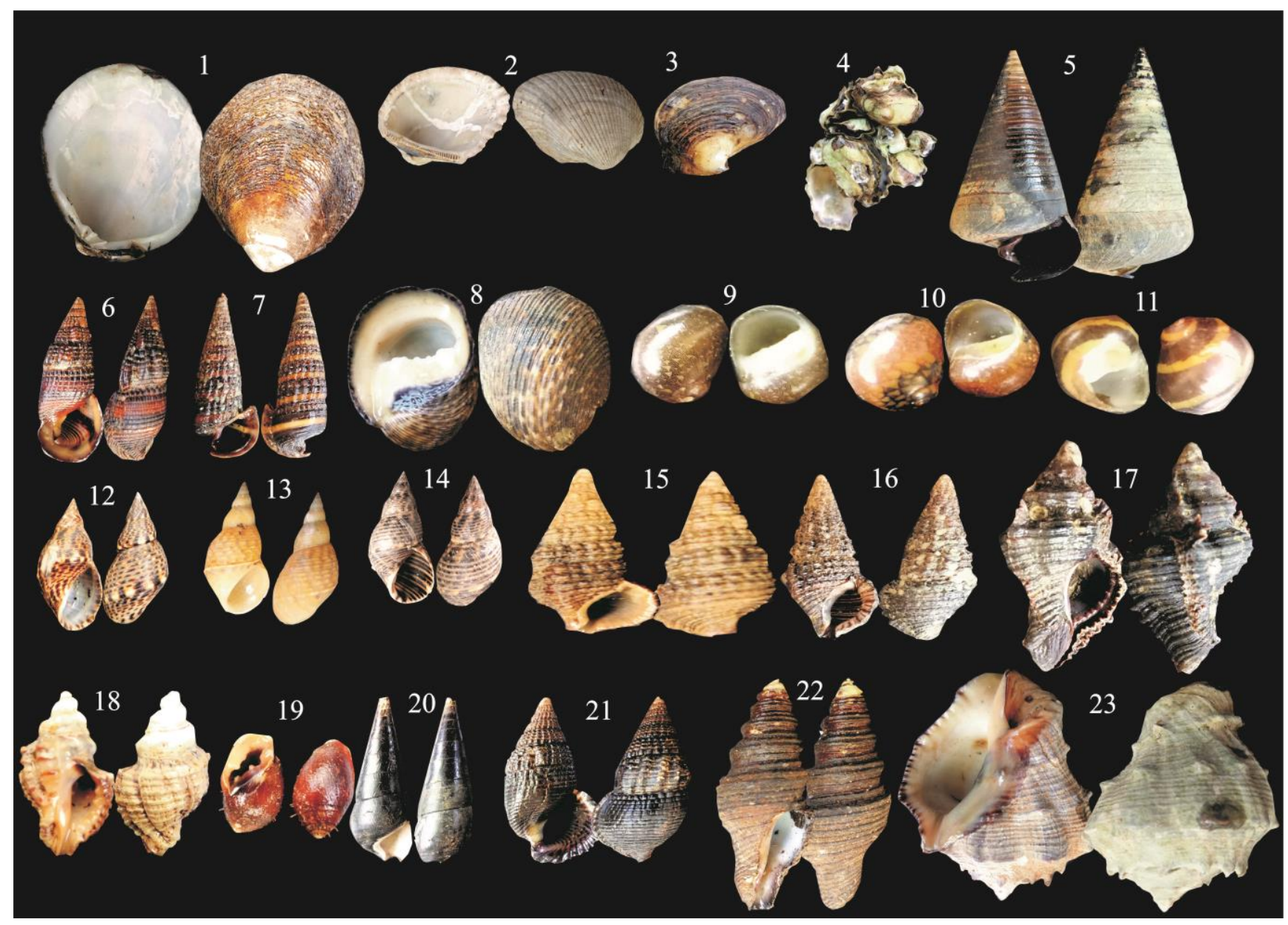

Figure 2. Molluscs in several mangrove ecosystem of Kolaka coastline, Southeast Sulawesi, Indonesia: 1. G. erosa (60 mm/63 mm); 2. A. notabilis $(30 \mathrm{~mm} / 39 \mathrm{~mm}) ; 3$. I. ephippium $(27 \mathrm{~mm} / 25 \mathrm{~mm}) ; 4$. S. cucullata $(35 \mathrm{~mm} / 20 \mathrm{~mm}) ; 5$. T. telescopium $(75 \mathrm{~mm} / 39 \mathrm{~mm}) ; 6$. T. sulcata $(40 \mathrm{~mm} / 15 \mathrm{~mm}) ; 7$. P. incisa $(35 \mathrm{~mm} / 10 \mathrm{~mm}) ; 8$. N. planospira $(24 \mathrm{~mm} / 19 \mathrm{~mm}) ; 9$. C. oualaniensis $(4,9 \mathrm{~mm} / 4 \mathrm{~mm}) ; 10$. C. pulchellum $(5 \mathrm{~mm} / 4,5 \mathrm{~mm}) ; 11$. Clithon $\mathrm{sp} .(5 \mathrm{~mm} / 4 \mathrm{~mm}) ; 12$. L. pallescens $(22 \mathrm{~mm} / 14 \mathrm{~mm}) ; 13$. L. carinifera $(28 \mathrm{~mm} / 17 \mathrm{~mm}) ; 14$. L. intermedia $(16 \mathrm{~mm} / 10 \mathrm{~mm}) ; 15$. C. corallium $(25 \mathrm{~mm} / 15 \mathrm{~mm}) ; 16$. C. pellucida $(22 \mathrm{~mm} / 6 \mathrm{~mm}) ; 17$. C. capucinus $(65 \mathrm{~mm} / 35 \mathrm{~mm}) ; 18$. D. margariticola $(17 \mathrm{~mm} / 8 \mathrm{~mm}) ; 19$. C. aurisfelis $(10 \mathrm{~mm} / 6 \mathrm{~mm}) ; 20$. F. Ater $(54 \mathrm{~mm} / 14 \mathrm{~mm}) ; 21$. B. multiformis $(42 \mathrm{~mm} / 15 \mathrm{~mm}) ; 22$. L. polytropa $(61 \mathrm{~mm} / 18 \mathrm{~mm}) ; 23$. V. myristica $(59 \mathrm{~mm} / 38 \mathrm{~mm})$ 

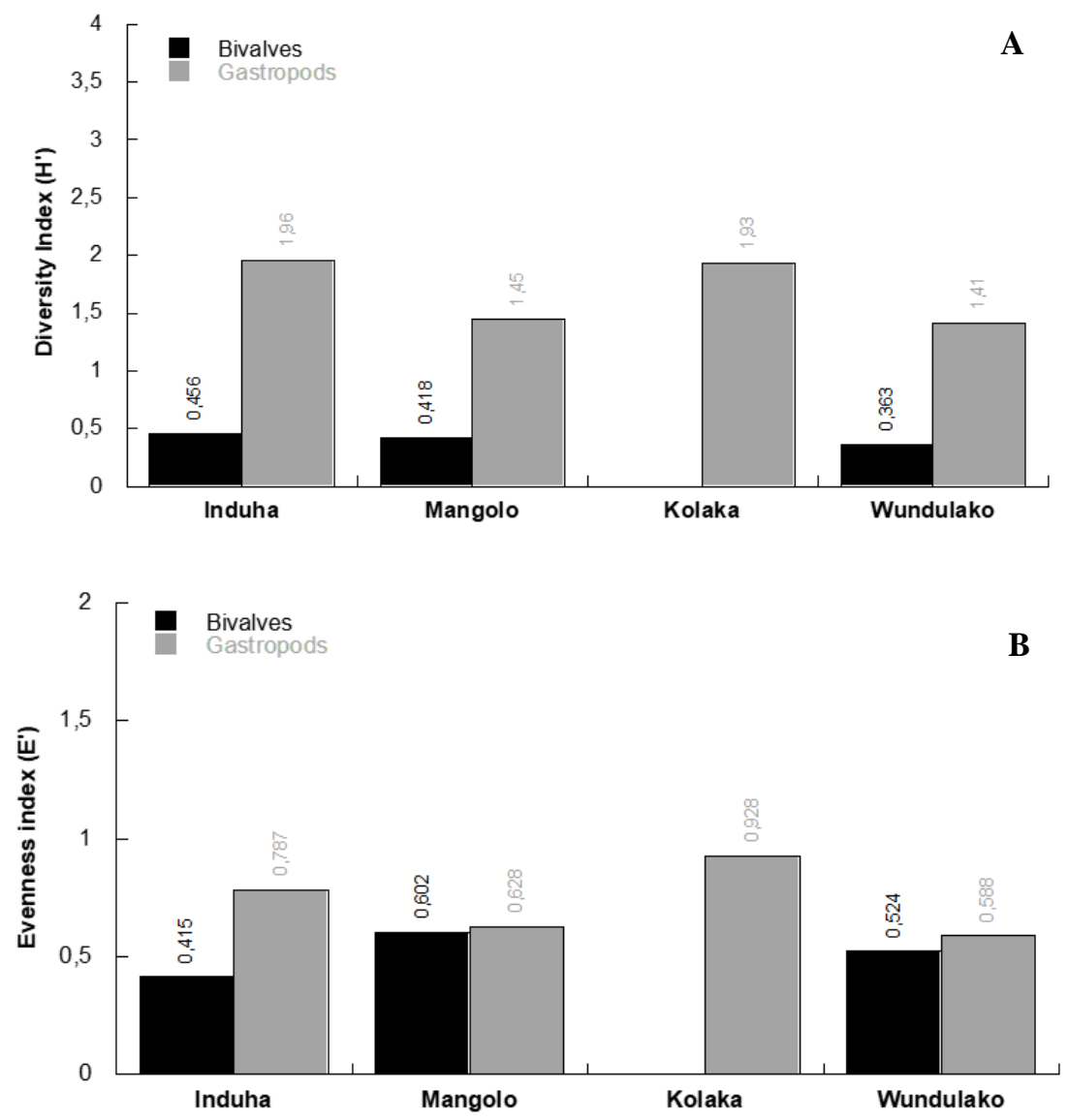

Figure 3. A. Diversity index $\left(\mathrm{H}^{\prime}\right)$ and B. Evenness index ( $\left.\mathrm{E}^{\prime}\right)$ of mollusks in several mangrove ecosystems of Kolaka coastline, Southeast Sulawesi, Indonesia

Furthermore, there were 21 epifauna species, namely $C$. oualaniensis, C. pulchellum, Clithon sp., T. telescopium, $T$. sulcata, $P$. incisa, $V$. myristica, $L$. polytropa, $B$. multiformis, F. ater, C. aurisfelis, D. margariticola, C. capucinus, C. pellucida, C. corallium, I. ephippium, S. cucullata, $N$. planospira, L. pallescens, $L$. carinifera, and $L$. intermedia. Two infauna species were G. erosa dan A. notabilis.

The index result of Shannon-Wiener diversity in allocations is different (Figure 3). The diversity index of gastropods in Induha mangrove area is higher (1.96) if compared within Tahoa (1.93), Mangolo (1.45), and Towua (1.41). Based on Bivalvia diversity, Induha is more diverse (0.45) than Mangolo (0.41) and Towua (0.36). Meanwhile, bivalve is not found in Tahoa. All gastropod diversity index in all four locations is still categorized in middle diversity $\left(1 \leq \mathrm{H}^{\prime} \leq 3\right)$, yet for Bivalvia in all locations is considered low $\left(\mathrm{H}^{\prime}<1\right)$.

The index value of mollusks diversity, both Bivalvia and gastropod in the mangrove ecosystem in Induha is fairly higher than in the other three locations. This serves as an impact on the mangrove ecosystem as the good habitat of mollusks. Even though land conversion appears in the location but it does not change the majority of the mangrove ecosystem. This is discovered by research from Hasidu et al. (2020; data not shown) revealing that the mangrove ecosystem in Induha around fish and shrimp pond is relatively good. Candri et al. (2020) explain that the environmental health status of the mangrove ecosystem can be seen from the existence of its associated organisms as catalysts. Furthermore, Baderan et al. (2019) explain that a diversity index can describe the complexity of the ecosystem.

Pileou's evenness index of both Bivalvia and gastropod also indicate the differences in one certain of mangrove ecosystem area (Figure 3). The highest evenness index of gastropod occurs in Tahoa (0.92) followed by Induha (0.78), Mangolo (0.62), and Towua (0.58). Different from the gastropod, the highest Bivalvia evenness index of the mangrove ecosystem is in Mangolo (0.60) and followed by Towua (0.52), and Induha (0.41). The Bivalvia evenness index in Tahoa is zero $\left(E^{\prime}=0\right)$ due to the absence of Bivalvia species in this location. 

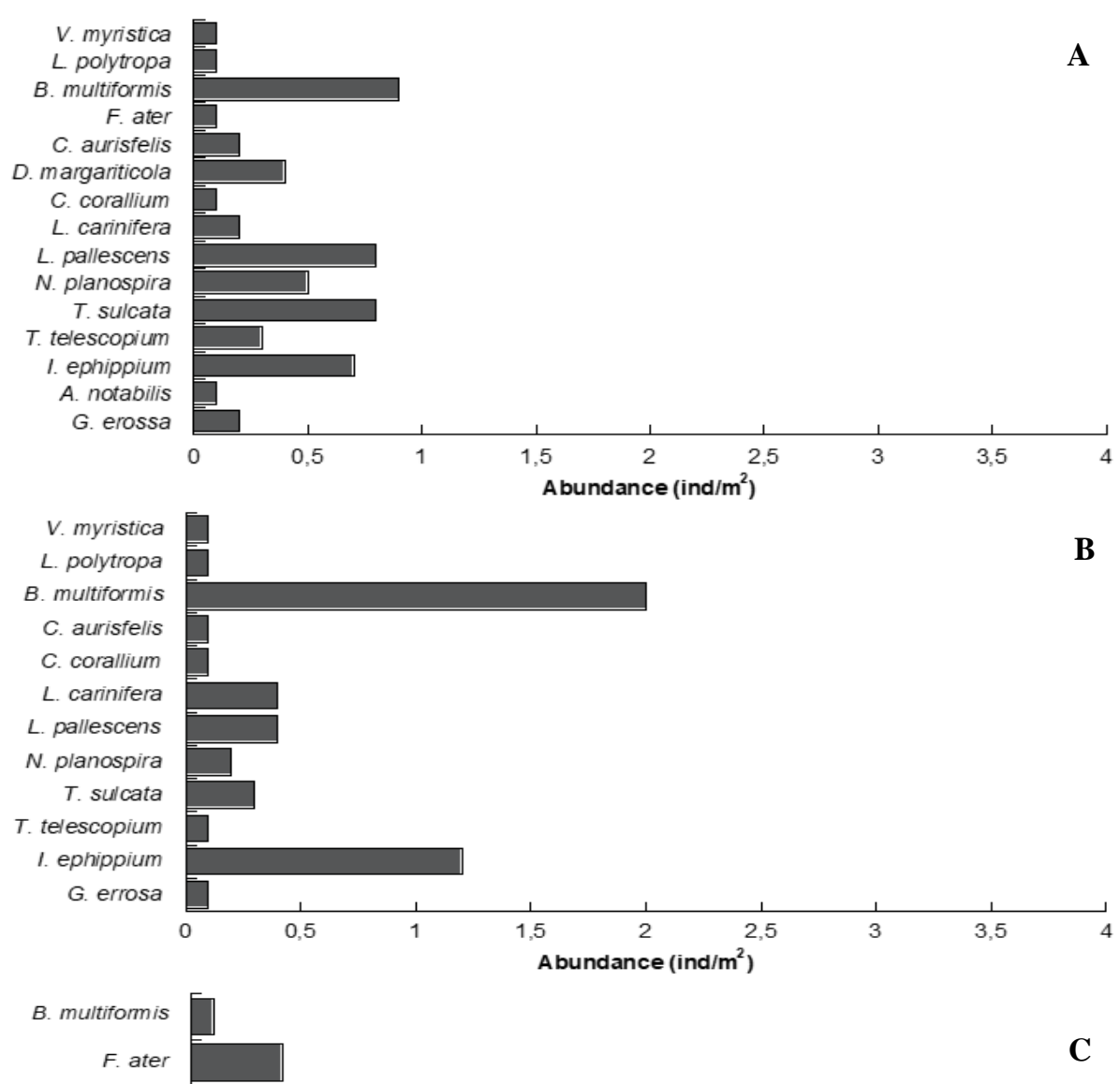

C. capucinus

L. intermedia

L. carinifera

Clithon sp.

N. planospira

T. sulcata

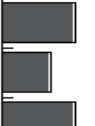

C
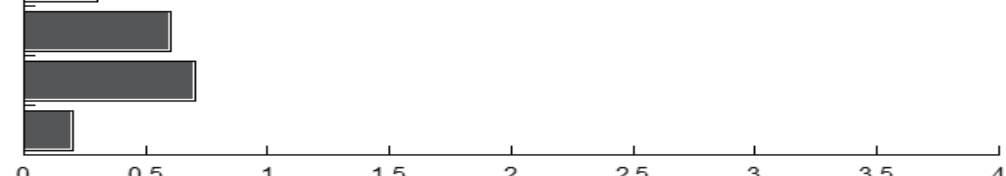

Abundance (ind $/ \mathrm{m}^{2}$ )

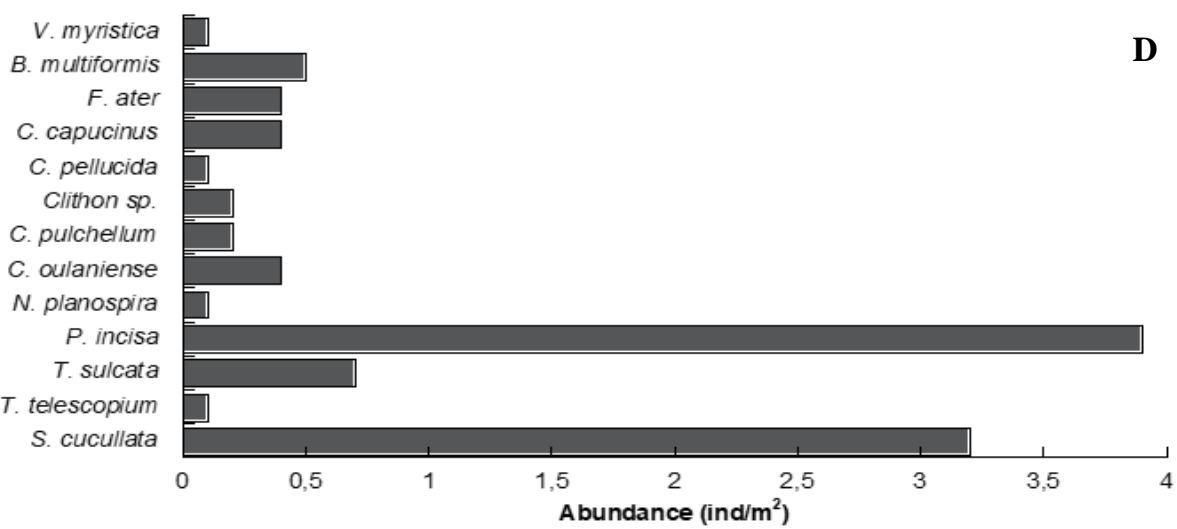

Figure 4.The abundance of mollusks in each mangrove ecosystem of Kolaka coastline, Southeast Sulawesi, Indonesia. A. Induha; B. Mangolo; C. Tahoa; D. Towua

The evenness index of gastropods in Kolaka is categorized as a very good condition category $\left(\mathrm{E}^{\prime}>0.8\right)$. It means that the condition of community structures is still maintained because the number of each species in these locations are not different. (Asadi et al. 2018) suggested that the mollusks community with the evenness index 0.9 , indicated the ecosystem's stability. The value of the evenness index is close to 1 indicating that the number of individuals is almost the same. Otherwise, if the evenness index is close to 0 , it indicates that the number of 
individuals is different and there is a dominance (Baderan et al. 2019). The mangrove ecosystem in Tahoa, Induha, and Mangolo are categorized in a good evenness index for gastropods (E' 0.61-0.80). Nevertheless, Towua is included in the medium category for gastropods $\left(E^{\prime}=0.41-0.60\right)$. Meanwhile, all locations are a medium category for bivalves.

The abundance of mollusks in the locations (Figure 4) reveals various results in each location. Of all locations, the abundance of each location is approximately 0.1 to 3.9 $\mathrm{ind} / \mathrm{m}^{2}$. Four species have a high rate of abundance, namely $P$. incisa $\left(3.9 \mathrm{ind} / \mathrm{m}^{2}\right), \quad S$. cucullata $\left(3.2 \mathrm{ind} / \mathrm{m}^{2}\right), B$. multiformis $\left(2 \mathrm{ind} / \mathrm{m}^{2}\right)$ as well as I. ephippium $\left(1.2 \mathrm{ind} / \mathrm{m}^{2}\right)$. This result is remarkably less than the result obtained by (Manullang and Leidonald 2018) and found out the density of gastropods between 20 to $31 \mathrm{ind} / \mathrm{m}^{2}$ in mangrove stands.

The same result is confirmed by Candri et al. (2020). They found that the abundance of mollusks species is considerably higher than the result of this research, namely $88.4 \mathrm{ind} / \mathrm{m}^{2}$ in unrehabilitated location and $50.26 \mathrm{ind} / \mathrm{m}^{2}$ in the rehabilitated location of the mangrove ecosystem. The low abundance of this research is probably caused by land degradation. Besides, opening land for ponding industries also occurred in the research location (Figure 1). This, consequently, causes the loss of mollusks' habitat. This perception is in line with Ernanto et al. (2010) who argue that the activities occurring on and around the land of the mangrove ecosystem influence the densities of mollusks, particularly gastropod.

The number of mollusks species is different from other locations in Indonesia (Table 2). Candri et al. (2018) found that the number of species of mollusks in Lombok island is more (42 gastropods and 5 bivalves) than in this study. The same result is declared by Islami and Mudjiono (2009) that the number of mollusk species in Ambon bay is more than in this study site (24 gastropods and 9 bivalves). On the other hand, Baderan et al. (2019) figure out that there are not many differences between Kolaka coastal line mollusks from North Sulawesi (21 gastropods and 4 bivalves). Kolaka coastal line experiences degradation and conversion causing the loss of habitats of mollusks, and the number of mollusks decreased. This result is still higher compared to Aceh, Tanah Laut, Brebes, and Padang (Table 2). Irma and Sofyatuddin (2012) found 14 species of gastropods and 5 species of bivalves in Aceh, while Nurfitriani et al. (2019) found 10 species of gastropods in Brebes, Central Java, and (Yolanda et al. 2015) found 15 species of gastropods in West Sumatra. The information of mollusks diversity in the mangrove ecosystem in Indonesia is unoptimal, especially in Southeast Sulawesi considering mollusks diversity is an important live being to support the conservation effort. Therefore, it needs more research about mollusks diversity in the mangrove ecosystem in Southeast Sulawesi.

Generally, degradation of the mangrove ecosystem which occurs in several regions in Southeast Sulawesi is caused by several factors, such as illegal logging and conversion of the mangrove ecosystem. This is supported by Rudia et al. (2019), who found that mangrove degradation in Towea island, Southeast Sulawesi was caused by the local people who cut mangrove trees for several cleared land for pond industry. Mangrove ecosystem at the surrounding area of Rawa Aopa Watumohai national park, Southeast Sulawesi has to encounter the same problem (Analuddin et al. 2015). The lost biodiversity and decreasing mangrove potentials will still be occurring if the mangrove ecosystem is disregarded. The mangrove revegetation probably could increase the mollusks' diversity in the ecosystem. Zvonareva et al. (2015) found that the species diversity of gastropods, especially opportunistic eurybiotic species, increases in the mangrove revegetation area. It is crucial to restore and support the sustainability of the coastal ecosystem because of the links to the organism and mangrove by-products. In addition, seasonal observation of mollusks is needed regarding the diversity of mollusks that exist in mangrove ecosystems and become a basic biodiversity data of mollusks community in Kolaka coastline (Baharuddin and Zakaria 2018), it could also be basic information to manage the sustainability of natural resources, because it has positive impacts to the fisheries (Puryono and Suryanti 2019).

\section{ACKNOWLEDGMENTS}

This research is supported by Universitas Sembilanbelas November Kolaka, Indonesia. Thank you to the LPPM Chairman of Universitas Sembilanbelas November Kolaka for the research recommendation letter, No. 016/UN56D/LT 2020, WEBcare, as well as to the local government that has approved me to do this research.

\section{REFERENCES}

Aksornkoae S. 1993. Ecology Management of Mangroves. IUCN Wetland Program. IUCN, Bangkok.

Analuddin K, Jamili, Septiana A, Izal, Fajar LOA, Raya R, Sahidin, Rianse U, Rahim S, Alfirman, Sharma S, Nadaoka K. 2015. Aboveground biomass status and management effort of unprotected mangrove forest at the surrounding areas of Rawa Aopa Watumohai National Park, Indonesia. Advances in Environmental and Geological Science and Engineering. ISBN: 978-1-61804-314-6.

Analuddin K, Kadidae LO, Haya LOMY, Septiana A, Sahidin I, Syahrir L, Rahim S, Fajar LOA, Nadaoka K. 2020. Aboveground biomass, productivity and carbon sequestration in Rhizophora stylosa mangrove forest of Southeast Sulawesi, Indonesia. Biodiversitas. 21 (4): 1316-1325. DOI: 10.13057/biodiv/d210407.

Analuddin K, Masa W, Sarlyiana WO, Rahim S. 2013. The spatial trends in the community structure of gastropod assemblages in the coastal area of TomiaIslan, Wakatobi Marine National Park, Indonesia. Intl J Dev Res 3 (11): 162-167.

Asadi MA, Iranawati F, Andini AW. 2018. Ecology of bivalves in the intertidal area of Gili Ketapang Island, East Java, Indonesia. AACL Bioflux 11 (1): 55-56.

Baderan DWK, Hamidun MS, Utina R, Rahim S, Dali R. 2019. The abundance and diversity of Mollusks in mangrove ecosystem at coastal area of North Sulawesi, Indonesia. Biodiversitas 20 (4): 987993. DOI: 10.13057/biodiv/d20040.

Baharuddin N, Zakaria NA. 2018. The biodiversity and conservation status of the marine gastropod (Mollusca; Gastropoda) in Pulau Bidong, Terengganu, Malaysia. AACL Bioflux 11 (4): 988-1000.

Bhosale MM, Mugale RR, Yadav SR, Naveen-Kumar BT, Barik P. 2016. Distribution of Bivalves and Gastropods along Ratnagiri Coasts Maharastra India. Indian J Ecol 43 (2): 413-417.

Candri DA, Junaedah B, Ahyadi H, Zamroni Y. 2018. Keanekaragaman Moluska pada Ekosistem Mangrove di Pulau Lombok. BioWallacea 
Jurnal Ilmiah Ilmu Biologi. 4 (2). 88-93 ISSN: 2442-2622. DOI: .29303/biowal.v4i2.140. [Indonesian]

Candri DA, Sani LH, Ahyadi H, Farista B, Virgota A. 2020. The composition of mollusks in mangrove ecosystem conservation area Bagek Kembar, West Lombok. IOP Conf Ser Earth Environ Sci 846: 012020. DOI: 10.1088/1755-1315/486/1/012020.

Cannicci S, Burrows D, Fratini S, Smith TJ, Offenberg J, DahdouhGuebas F. 2008. Faunal Impact on Vegetation Structure and Ecosystem Function in Mangrove Forest. A review. Aquat Bot 89:186-200.

Dey A. 2006. Handbook on Mangrove Associate Molluscs of Sundarbans. Zoological Survey of India, Kolkata.

Dharma B. 1991. Siput dan Kerang Indonesia II. PT. Sarana, Jakarta. [Indonesian]

Dolorosa RG, Dangan-Galon F. 2014. Species richness of bivalves and gastropods in Iwahig River-Estuary, Palawan, the Philippines. Intl J Fisheries and Aquatic Studies. 2 (1): 207-215.

English S, Wilkinson C, Baker V. 1997. Survey manual for tropical marine resources 2nd ed. Australian Institute of Marine Science, Canberra.

Ernanto R, Agustriani F, Aryawati R. 2010. Struktur komunitas gastropoda pada ekosistem mangrove di muara sungai batang ogan komering ilir sumatera selatan. Maspari J 1: 73-78. [Indonesian]

Flores-Garza R, García-Ibáñez S, Flores-Rodríguez P, TorreblancaRamírez C, Galeana-Rebolledo L, Valdés-González A, Suástegui Zárate A, Violante-González J. 2012. Commercially important marine mollusks for human consumption in Acapulco. Nat Resour 3 (1): 1117. DOI: $10.4236 / \mathrm{nr} .2012 .31003$.

Htwe, Oo NN. 2019. Marine gastropods and bivalves in the mangrove swamps of Myeik Areas, Taninthayi Region, Myanmar. J Aquac Mar Biol 8 (3): 82-93. DOI: 10.15406/jamb.2019.08.00246.

Irma D, Sofyatuddin K. 2012. Diversity of Gastropods and Bivalves in mangrove ecosystem rehabilitation areas in Aceh Besar and Banda Aceh districts, Indonesia. AACL Bioflux 5 (2): 55-59.

Islami MM, Mudjiono. 2009. Komunitas moluska di perairan teluk ambon, provinsi maluku. Oseanologi dan Limnologi di Indonesia. 35 (3): 353-368. [Indonesian]

Kantharajan G, Pandey PK, Krishnan P, Samuel VD, Bharti VS, Purvaja R. 2017. Molluscan Diversity in the Mangrove Ecosystem of Mumbai, West Coast of India. Regional Stud Mar Sci 14: 102-111. DOI: 10.1016/j.rsma.2017.06.002.

Kartika S, Mu Y. 2014. A study on Indonesian mollusk fishery and its prospect for economy. Intl J Mar Sci 4 (5): 61-66. DOI 10.5376/ijms.2014.04.0005.

Kristiningrum R, Lahjie AM, Masjaya, Yusuf S, Ruslim Y. 2019. Specie diversity, stand productivity, aboveground biomass, and economic value of mangrove ecosystem in Mentawir Village, East Kalimantan, Indonesia. Biodiversitas 20: 2848-2857. DOI 10.13057/biodiv/d201010

Manullang T, Bakti D, Leidonald R.2018. Structure of gastropod communities at mangrove ecosystem in Lubuk Kertang Village, West Berandan Subdistrict, Langkat District, North Sumatera Province. IOP Conf Ser Earth Environ Sci 122: 012103. DOI: 10.1088/17551315/122/1/012103.

Murniati DC, Pratiwi R. 2015. Kepiting Uca di Hutan Mangrove Indonesia: Tinjauan Aspek Biologi dan Ekologi untuk Eksplorasi LIPI Press, Jakarta. [Indonesian]

Ngor PB, Sor R, Prak LH, So N, Hogan ZS, Lek S. 2018. Mollusc fisheries and length-weight relationship in Tonle Sap flood pulse system, Cambodia. Ann Limnol Intl J Lim 54: 34 . DOI: 10.1051/limn/2018026.

Nurfitriani S, Lili W, Hamdani H, Sahidin A. 2019. Density Effect of Mangrove Vegetation on Gastropods on Pandansari Mangrove Ecotourism Forest, Kaliwlingi Village, Brebes Central Java. World Sci News 133: 98-120.

Odum EP, Barrett GW. 2004. Fundamentals of Ecology. 5th ed. Brooks Cole, Belmont, CA

Puryono S, Suryanti S. 2019. Gastropod diversity in mangrove forests of Mojo Village, Ulujami Subdistrict, Pemalang District, Indonesia. J Ecol Eng 20 (1): 165-173. DOI: 10.12911/22998993/93940.

Rudia LOAP, Bahtiar B, Jamili J, Muhsin M, Nasaruddin N. 2019. Diversitas Gastropoda Berdasarkan Tingkat Kerusakan Mangrove Di Pulau Towea Kabupaten Muna Sulawesi Tenggara. BioWallacea: Jurnal Penelitian Biologi 6 (1). DOI: 10.33772/biowallacea.v6i1.8742. [Indonesian]

Saleky D, Setyobudiandi I, Toha HA, Takdir M, Madduppa H. 2016. Length-weight relationship and population genetic of two marine gastropod species (Turbinidae: Turbo sparverius and Turbo bruneus) in the Bird Seascape Papua, Indonesia. Biodiversitas 17 (1): 208-217. DOI: $10.13057 /$ biodiv/d170130.

Satheeshkumar P, Khan AB. 2012. Influence of environmental parameters on the distribution and diversity of molluscan composition in Pondicherry Mangroves, Southeast Coast of India. Ocean Sci J 47 (1): 61-71. DOI: 10.1007/s12601-012-0006-6.

Satyanarayana JE. Krishna PV. 2017. Species diversity and distribution of molluscan fauna from estuary and mangroves (Coringa Wildlife Sanctuary) of East Godavari Estuarine Ecosystem, Andhra Pradesh, India. Intl J Adv Res. DOI: 10.21474/IJAR01/3094.

Septiana A, Harlis W O, Analuddin K. 2016. Bioprospecting mangroves: antioxidant source and habitat for the endemic Bubalus sp. in Rawa Aopa Watumohai National Park, Indonesia. Malays Appl Biol 45 (1): 23-34.

Sharma KK, Bangotra K, Saini M. 2013. Diversity and distribution of Mollusca in relation to the physicochemical profile of Gho-Manhasan stream, Jammu (J \& K). Intl J Biodiv Conserv 5 (4): 240-249. DOI: 10.5897/IJBC12.127.

Suratissa DM, Rathnayake U. 2017. Effect of pollution on diversity of marine gastropods and its role in trophic structure at Nasese Shore, Suva, Fiji Islands. J Asia-Pac Biodiv 10: 192-198. DOI: 10.1016/j.japb.2017.02.001

Szabó K, Amesbury JR. 2011. Molluscs in a world of islands: The use of shellfish as a food resource in the tropical island Asia-Pacific region. Quater Intl 239 (1-2): 8-18. DOI: 10.1016/j.quaint.2011.02.033

Yadav R, Malla PK, Dash D, Bhoi G, Patro S, Mohapatra A. 2019. Diversity of gastropods and bivalves in the mangrove ecosystem of Paradeep, east coast of India: a comparative study with other Indian mangrove ecosystems, Molluscan Res. DOI: 10.1080/13235818.2019.1644701

Yolanda R, Syaifullah S, Nurdin J, Febriani Y, Muchlisin ZA. 2015. Diversity of gastropods (Molluscs) in the mangrove ecosystem of the Nirwana Coast, Padang City, West Sumatra. AACL Bioflux 8 (5): 687-693.

Zvonareva S, Kantor Y, Li X, Britayev T. 2015. Long-term monitoring of Gastropoda (Mollusca) fauna in planted mangroves in central Vietnam. Zool Stud 54 (1): 54-39. DOI: 10.1186/s40555-015-0120-0.

Zvonareva, S, Kantor Y. 2016. Checklist of gastropod molluscs in mangroves of Khanh Hoa province, Vietnam. Zootaxa 4162 (3): 401437. DOI: 10.11646/zootaxa.4162.3.1 